\title{
Chanting Grief, Dancing Memories: Objectifying Hawaiian laments
}

\author{
Adrienne L. Kaeppler
}

\section{Introduction}

Throughout Polynesia, death and funerals were, and in some islands still are, some of the most important social events, with unbounded grief often expressed. Immediate expressions of grief might be voiced in special ways and categorised with special terms, such as tangi in Aotearoa (New Zealand), and poetic eulogies might be composed some time after a death has occurred. Though these are often mentioned in ethnographic literature, not many studies have been published on this specialised category of music/poetry. In the Oceania volume of the Garland Encyclopedia of World Music, ${ }^{1}$ for example, most authors of Polynesian music articles devote only a few sentences to laments, and do not focus on their importance, style or poetry. On the other hand, the concept of laments has been used in contemporary expressive culture. For example, Samoan-Japanese artist Shigeyuki Kihara styles the performance of his recent work 'Taualuga: the last dance' as a lament for the loss of Samoan culture through colonisation. ${ }^{2}$ Between these two poles are passing mentions of sad songs as laments - for example, a Cook Islander sings a song about her dead mother, but not in a distinctive style, $^{3}$ or a danced 'lament for a kite' as a metaphor for a missing loved one (in the Human Studies Film Archives of the Smithsonian Institution). This essay is a step towards filling the void in recent literature about Hawaiian laments by exploring the poetry of traditional and modern laments known as kanikau and the changing performances and contexts of Hawaiian grieving.

In socially stratified Hawai'i, as known in the nineteenth century, grief over an individual's death was expressed and commemorated visually, verbally and with bodily movement, its elaboration depending on one's place in society. The passing of a high-ranking chief was an appropriate occasion for self-mutilation, such as knocking out teeth or inflicting wounds. Shark teeth were mounted into

\footnotetext{
1 Kaeppler, Adrienne L. and Love, J. W. (eds) 1998, Garland Encyclopedia of World Music. Volume 9: Australia and the Pacific Islands, Garland Publishing Company, New York.

2 Shigeyuki Kihara 2012, 'Taualuga: the last dance', Pacific at Te Papa, vol. 17, p. 4.

3 Alexeyeff, Kalissa 2009, Dancing from the Heart: Movement, gender, and Cook Islands globalization, University of Hawai ${ }^{i}$ Press, Honolulu, pp. xiii-xiv.
} 
wooden handles and used to cut oneself, hair was cut on one side of the head, ${ }^{4}$ and sometimes the tongue was tattooed. High chief-ess Kamamalu (c. 1800-24, the wife of Liholiho, Kamehameha II), at the death of Keopuolani (her motherin-law), tattooed her tongue and remarked: 'Pain, great indeed, but greater my affection!'5 Jacques Arago, during his 1819 visit to Hawai'i, noted that the body of Ka ahumanu (a wife of Kamehameha I, c. 1758-1819) bore the marks of a great number of burns and incisions that she inflicted on herself at the death of her husband. ${ }^{6}$ This convention evolved into the practice of tattooing a chief's name and the date of death on one's arm, as illustrated by J. Alphonse Pellion during the voyage of Freycinet. At the highest level of society, the bones of dead chiefs were encased in coconut-fibre sennit caskets made of fibre cords that had protective prayers chanted into them during fabrication by a specialised kahuna (priest). This objectified prayer stayed with the bones as a perpetual kapu (taboo).

\section{'Crystallized Voice of Grief'}

More relevant to us here is poetry composed and/or performed for the dead, which has become objectified and preserved in written form since the nineteenth century. Traditional Hawaiian music is based on poetry, much of which is intoned/chanted/sung with a small number of pitches and in a narrow melodic range without polyphony. Vibrato, called $~ i `$, is an important element of style and varies with the type of intoned poem. A well-developed lament genre called kanikau extols the virtues of the deceased and provides an appropriate medium for the stylised wailing engaged in at the time of death. Not many laments or dirges have been sound recorded because of Hawaiians' reluctance to sing a dirge when no actual death has occurred or is imminent. A few were recorded on wax cylinders, primarily in the 1920s and 1930s, but not in context. One of these recordings comes from the story of the volcano goddess Pele and her sister Hi iaka, where it is used to tell part of the narrative. ${ }^{7}$ A few wax cylinders, recorded after the fact, preserve the sung poetry that was remembered from the death of a high chief. Another recorded example is a generalised poem that could be used at the death of a spouse. These wax cylinders and archival texts can be found in the library and archives of the Bishop Museum in Honolulu.

Kanikau were chanted/sung in a highly emotional style called ho'ouēue (ho'ouweueue $)$, characterised by a highly developed vibrato ( $i ` i)$, and often

\footnotetext{
4 Kamakau, Samuel M. 1964, 'Ka po`e kahiko, the people of old', Translated by Mary Kawena Pukui, Ke Kumu Hawaii, [Semi-monthly Hawaiian newspaper], Special Publication 51, Bishop Museum Press, Honolulu, p. 34.

5 Ellis, Rev. William 1827, Narrative of Tour Through Hawaii, London, p. 122.

6 Arago, Jacques 1823, Narrative of a Voyage Round the World, 1817-1820, London, p. 92.

7 Emerson, Nathanial B. 1915, 'Pele and Hiiaka. A myth from Hawaii', Honolulu Star-Bulletin, p. 214.
} 
included outbursts of wailing. Today, only a few accomplished chanters continue to voice this difficult style of chanting. The emotion that kanikau, embodied as ho'ouêue, conveyed was recently characterised by hula and chant teacher Noenoelani Zuttermeister as follows:

The pain of loss is heard in the voice while crying and wailing. The wailing is gut-wrenching, a person can feel the chanter's sorrow. One can compare the feeling to an opera, even though the listener is unfamiliar with the language one can still feel the emotion. The sound to me was a little scary yet at the same time the feeling of love is felt, seen and heard. The chanter that I heard a couple of times when I was younger chanted her connection with the deceased and while chanting she let people know what a great loss there was. ${ }^{8}$

Relying on improvised or preset texts, kanikau serve as a means through which individuals cry and explain their sorrow that the deceased has passed away. They are also poetic creations in praise of the one departed. Delivered in a pitched, rhythmic form, the texted weeping can show immediate grief or be performed at a funeral or memorial. Since the nineteenth century, they have been written down and sometimes published.

Writing in 1895, Reverend C. J. Lyons characterised this chanting/wailing sound as the 'crystallized voice of grief'. ${ }^{9}$ I use this as an apt metaphor for making the emotion of grief into something clear and almost tangible by adapting the dictionary figurative definition of crystallised: 'make or become definite and clear.' ${ }^{10}$ That is, grief is made crystal clear in the voicing of a kanikau.

Lyons provides an example of a lament composed by native Hawaiian historian David Malo for Queen Ka`ahumanu (a wife of Kamehameha), who died in 1832. What interested Reverend Lyons was that the coming of Christianity did not bring an end to the composition of kanikau, but that pre-Christian sentiments were replaced with Christian ones.

Miha lanaau i kuakahiki ka newa na,

Ke kaha na ka leina aku nei liuliu,

Liua paia aku nei i Kuanalia,

I analipo $i$ analio.

Lilo aku la i ka paia ku a Kane,

I ke ala muku maawe ula a kanaloa,

Keehikulani aku la ka hele ana,

E malolo kiha ka haku leiohua,

8 Noenoelani Zuttermeister, Personal communication, May 2011.

9 The Friend, vol. 53, no. 8 (August 1895), p. 57.

10 The Oxford American College Dictionary 2002, Oxford University Press, Honolulu. 
Kelii i Kuluhiolani aui newa aku nei,

I lele aku na i ke kohi ana o ka pawa,

I ke anohia kohikohi ana o ka po,

Ka lilo ana ia la,

Iala, o----i----e.

Oia hoi, he uwe, he aloha ia oe, a----

Pakoni hu i ke aloha loku i ke ake,

Wehe wahi ka pilipaa o ka houpo,

Naha ka paa, ke pe'kua o ke kanaka,

Helelei, hiolo ke pua o ke waimaka,

Lele lei-o, ho loko i ka nihi,

Mihi o ke aloha o juu haku maoli,

A kaawale okoa ia loha ana,

Aloha aku o ke aloha hoahanau,

Aole he hoahanau ponoi no'u;

He hanauna ku okoa i loi' ka Haku,

I hanaula e ka Uhane Hemolele,

E ka Makua hookah o makou,

I pilikana ilaila e wena aku ai,

Ilina inoa kaikuwahine no'u,

Auwe no hoi kuu kaikuwahine,

Kuu hoa hooikaika i ka luhi leo e, ia,

Iala, o---i---e.

Oia no o o eke aloha, ka u a loko a,

A, aloha oe ka haku kau o ka manao,

Ke kookoo ka leo e ili aku ai,

E imi po ai o ka waiwai ka pono e, ia, Iala, o---i---e.

o ka wahine alo ua waahila o Kona,

Nihi makani alo ua, Kukalahale,

Noho anea kula wela ia o Pahoa,

Wahine holo ua haao Nuuanu e, ia,

Holo a nele i ka pono, ua paoa,

Ua hihi aku, hihi mai, ke aloha ole,

Aole pono, he enemi noho pu e, ia.

Aha, aia 'ku la i he lani,

Ka uhane a ke kino wailua,

Kino akalau pahoahao,

Oiwi haona hiona e,

Haili aka, kino ano lani,

Hoa anela o ka lani ma,

Ke luana wale la i ka lani,

Ua luakaha ka noho ana, 
Ke halelu ia la ilaila,

Iloko o ka Paredaiso nani,

I kea o mau loa o ka Haku e, ia,

o ko kakou mau Haku no ia,

o ka Haku mau no ia, oia no.

o ka Haku mau no ia, oia no.

o ka manao ia a.loko e ake nei,

E ake aku nei, e, e.

Mei 22, 1834. Davida Malo

After Death (Translated by Curtis J. Lyons)

Ceasing from storm, the sea grows calm and glassy. Like a puff of wind flitting over it, so her spirit glides away to the far regions beyond Kahiki. (The word for far away shores.) She flies; averting her eyes, she fades away in the wild mists of the north-land, the deep, dark, mysterious north.

She has gone from us, to the courts of Kane, treading royally the redstreaked path of the rosy dawn; the misty, broken road to Kanaloa.

An ebbing tide flows out, laden with departing wealth. The chief is turning away, sinking to sleep, drifting away. She fled at the first gleam of the dawn, at the faint ending of the cut-off night. Then was her departure.

Oh our beloved one! Our departed one! Our bemoaned one!

The heart beats tumultuously; it throbs within us; it strains us; it breaks the walls around it.

Oh the pain, the breaking up, the rushing of tears, the falling of the flowers scattered of grief.

We are borne away, carried away, the very depths of us are torn from us by this passionate grief.

Our true liege lady was she, and I grieve. Love as to a sister is mine, yet not to a sister. Yea, a sister, chosen and separate in the Lord, born of the Holy Spirit, of the one Father of us all. Thus, thus I feel that she is mine to sorrow for. The precious name, sister, is indeed ours (to use) by dear inheritance. Alas, my sister! My beloved sharer in the sweet labor of the voice (i.e. conversation). Oh, my beloved! My beloved! Oh centre of thought! 
The voice is the staff that love leans upon. With the voice we seek common treasures together, sweet converse together. Gone---Gone--Gone!

O lady, seeking shelter from the Waahila rain of Kona, the cutting rain with the wind beating against the house gables! O lady, companion on the hot, sun-beaten plains of Pahoa! O lady, beloved, in the cold rain of Nuuanu! We flee together; there is nothing, all is in vain,---empty, forsaken. Confusion all tangled together; there is no more love, no more good; it is an enemy that is now with us! Alas!

The spirit of the shadowy presence, the spirit body is gone. The manyshadowed, the glorified, the transfigured body is beyond,---newfeatured, heavenly formed, companion of angels. She rests in the rich light of Heaven, she moves triumphant. She sings praise---psalms of joy in the paradise of glory, in the everlasting Lord. He is our Lord, the everlasting Lord. He indeed, in truth.

Such are the thoughts that burn within me, they burn and go out from me, thus I pour out my soul, my soul!

May 22, 1834. David Malo

In this example, the first few verses tell of the indigenous gods Kane and Kanaloa, while the second part tells of the Christian triune God. The ending finds Ka'ahumanu in heaven, a companion of angels. This acceptance of traditional Hawaiian musical/poetic forms by the well-respected Reverend Lyons was a factor in the preservation and continuance of the composition of kanikau.

Another early published example is a kanikau composed by Kahekili, the high chief of Maui Island at the time of Captain Cook's visit. ${ }^{11}$

11 From Ke Kumu Hawaii (18 February 1835, p. 64). The text was used as part of a workshop on 'Kaona and Inner Meaning', presented by Puakea Nogelmeier in 2010. English translation by Nogelmeier. 


\section{He mele kanikau na Kahekili no A dirge composed by Kahekili for ka make ana o kana aikane the death of his aikane}

Me he holoaau la i ka malie,

Ko kalaku, 'kalaku alo na moku,

Ka pewa, ka hiu, o Kanaloahaliua,

Ka halo na mahamah'e au nei;

Ka lele haohao' Kamehame Lanai;

Lana me he pikoi la, lana Maunaloa,

Ka olokea o na moku ilok'e kai, e,

Kuu hoa, kuu hoa pili o na kai awalu,

Mai ka ai nana iuka ke noho; la, e, eia, e;

Ke noho nei no ia me ke aloha,

Aohe wai maalili iho ai; laha

Kio e lana ka hau iluna o ke ki

Iluna o ka laau 'o miki ka wai, He wai e lu ana iluna o ka ili, He wai auau no ko laila kupa,

E maka ala ana $i$ ka wa ana o ke ao,

E pulale ana o awakea,

o inuhia e ka la ka wai;

Pau ka wai mihi hopo o ka eh'e,

o ka eha ia a ke aloha, he waimaka,

o kana ukana ia, ke hanini nei, e, eia.
As though a current borne in the calm,

Your release, the islands shiver in the presence,

The tail, the caudal fin of Kanaloahaliua,

The frontal fins, gill plates ahead, swimming along;

The wondrous flight of Kamehame Lanai;

Bouyant as a net floater, Maunaloa floats,

The criss-cross of the islands in the sea, e,

My companion, my dear companion of the eight seas,

Bring food, gaze inland, he dwells there, e, here, e,

Residing there, indeed, with affection, There is no water that could soothe it; it is widespread,

The dense mist emerges, drifting over the ti-plants

Over the trees, let the water be drawn Water that sprinkles upon the skin, Bathing waters for those who live in that place,

Watching for the emergence of day,

With noontime hastening along,

Let the waters be drunk up by the sun;

Let the fretful waters of regret over pain be gone,

It is the pain of love, tears,

Such is love's burden, pouring down, and here it is. 
In this poetic creation in praise of the one departed, Chief Kahekili extols the virtues of his aikane (friend of the same sex), and explains his sorrow that his friend has passed away. That is, Kahekili crystallises his emotion of grief in an appropriate medium.

\section{Visualising Grief}

Structured human movement was part of the rituals associated with a person's death, especially for those of high rank, in which the kanikau extolled the virtues of the deceased and related their genealogies and personal histories. Formalised movements accompanied wailing. These movements included: 1) locking the fingers of the hands and placing them behind the head; 2) stretching the hands and arms upwards, with palms turned towards each other; and 3) beating the breast. ${ }^{12}$ These formulaic movements associated with kanikau were usually not performed in association with musical instruments, may have been spontaneous (that is, not pre-choreographed into a specified sequence) and were probably personal rather than group responses to the mourning context. Hawaiian historian Samuel M. Kamakau, in a description of beating the breast while swaying the body during mourning, uses the term ha'a. He noted that the high chief Keoua 'was mourned by the chiefs with loud wailing and with swaying of the body (ma ka ha 'a ana) in token of grief'. These movements were called $h a^{\prime} a$, and, according to Kamakau, the mourner usually kneels with hands clasped behind the neck or thrown into the air or beating the breast while the body sways back and forth. ${ }^{13}$ The noted late nineteenth-early twentiethcentury dancer Keahi Luahine (1877-1937) explains that the movements that accompanied wailing denote signs of death and should be avoided in hula; however, the pa'iumauma - chest-slapping hula - may have developed from the movements that originally accompanied kanikau. Such a pa'iumauma/kanikau was recorded by W. M. Kalaiwa' a for Helen Roberts in the 1920s. ${ }^{14}$ The Bishop Museum published this sound recording on the album Nā Leo Hawai i Kahiko, Voices of Old Hawai $i:^{15}$

Ha`uha`u uwe, ha'uwē

Hu'iau uwe, hu'i e.

$H u^{\prime} i a^{\prime} o$ 'é, e hu'i e.
A sob, a sob, a wail,

A painful grief, painful grief,

A sharp pain, a sharp pain.

12 See notes by Kenneth P. Emory, 1933, from interviews with dance specialist Keahi Luahine, in the Bishop Museum Archives, Honolulu.

13 Kamakau, Samuel M. 1961, Ruling Chiefs of Hawaii, Kamehameha Schools Press, Honolulu, p. 75.

14 Roberts, Helen H. 1926, Ancient Hawaiian Music, Bishop Museum Bulletin 29, Honolulu, p. 189.

15 Tatar, Elizabeth 1981, Nā Leo Hawai i Kahiko, Voices of Old Hawai i, [Double album with notes and texts], Audio-Recording Collection Series No. 1, Department of Anthropology, Bishop Museum, Honolulu, Record 1 , side B, band 6 . 
The sung poetry and movements communicated grief to oneself and to those watching and listening for whom it was socially appropriate to acknowledge the performance. Although abstract or metaphorical concepts might be expressed, the reason for the performance derived from the emotions of grief.

\section{Grief, Praise, Society and Aesthetics}

Oratory was, and still is, important in Hawaiian society; the oratorical voice found in kanikau is still part of an aesthetic construction realised through metaphor and allusion called kaona, which was central to Hawaiian poetic texts even though they may never have had an oral public performance. When performed, emotions are expressed through affect-encoding words, such as aue (or auwe), and express relationships among the chanter, the deceased and those listening. Funerals show how the deceased is related to others, and kanikau demonstrate verbally how much and by whom he or she is beloved. Hence, funerals were, and are, the distilled essence of society and social relations realised through poetry spoken or sung. Puakea Nogelmeier has reminded us that, in addition, kaona is also the seed from which the poetry grew, not just the underlying meaning, ${ }^{16}$ and this can especially be seen in kanikau, whose poetry grew from grief.

Today laments retain their historical style but are seldom voiced in ho ouêue (emotional performance style of the kanikau), as this difficult chanting style is mastered by only a few. One of these is Ka upena Wong, who is often called up for eulogies or kanikau, which he composes and performs as ho'oueuee. A kanikau that he composed for Jim Bartels, the curator of 'Iolani Palace, was not performed, but was published in 2003 in the Honolulu Star-Bulletin:

Auē, auē no ho-'i e, auē!

Aia i hea ke wai lana mālie?

Ai(a) wale pu'e wai kupiki'ō

Pehea, no ke aha la, i aha `ia la?

Ua make `o Jim bartels, ua hala akula

Auē, ua 'eha au me ke kaumaha loa $i$

liko o' $u$, aue

Pa i a uma nā māmakakaua*

Ua hele aku `o Jim, ua hele ia i ke ala Ho $`$ 'ole mai
Oh my, oh gosh, oh!

Where are the quiet waters?

Only stormy, turbulent waters!

What happened, how come, why?

Jim Bartels died, he passed away

Oh how I ache with sad feelings inside of me, sad

The mämakakaua slap their chests in grief

Jim has gone away, he has gone on the road of no return

16 Nogelmeier workshop, October 2010. 
'O kona mau hoa ka pono a me ka pololei

Goodbye, aloha `oe e ku'u kaina, ku’u hoaloha maika $i$

'O 'oe no he keonimana hapa Hawai' $i$ he

kanaka u'i, na`auao, he lokomaika`i

Goodbye, aloha e ke keiki hānau o ka

‘̄ina, aloha!
Integrity and goodness are his companions

Goodbye, farewell to you, beloved brother, good friend

You were indeed an elegant, learned and gracious

part-Hawaiian gentleman

Goodbye, aloha o beloved native son of

Hawai i, aloha!

\footnotetext{
* He was a member of the Royal Society `Ahahui Māmakakaua, Daughters and Sons of Hawaiian Warriors. Source: Hawaiian and English text by Ka'upena Wong.
}

Still important today in Hawaiian society, funerals and the wakes that precede them are social functions in which the dead partake; however, kanikau voiced as ho 'oueue and the structured movements that accompanied them are seldom seen or heard. Instead, they have been replaced with spoken eulogies, written kanikau and hula. Most poignant are songs and dances directed towards an open casket. During the 2010 funeral of hula teacher Ceci Akim, her students and family members performed 'Lili' $\mathrm{u} \mathrm{E}^{\prime}$ and family members performed 'Ka Nohona Pilikai'. At the end of the service, her students performed the wellknown exit dance 'Keawe `O opa (Halehale Ke Aloha A i Ha 'iku E)' to lead the casket out of the funeral home to the hearse. Prior to the official start of the funeral service, people viewed the casket, a music group played Hawaiian music and people rose and spontaneously danced to the open casket. ${ }^{17}$

During the wake and huge funeral of well-known hula and chant teacher Kau i Zuttermeister in 1994, numerous students, friends and family members performed several hula facing the open casket. Her students and family members performed 'Nā pua lei 'ilima', composed and choreographed by Kau 'i, several times, both facing her open casket and, for the last time, when the closed casket remained in the aisle, waiting to be taken to the cemetery. Today, such performances are the most poignant of dancing memories.

\section{Conclusion}

Death is ever with us, and its interpretation, like that of all important events, is as significant as the fact itself. The interpretation of Hawaiian kanikau, either written or voiced as ho'ouêue, reveals the oratorical power and the poetic

17 Mary Jo Freshley, Personal communication, May 2010. 
expression of oral and written verbal art and the movements that objectify them. As this essay has noted, ho 'ouēue are seldom performed in public today and the movements that accompanied them during the nineteenth century have been replaced with hula performed to Hawaiian songs loved or composed by the deceased. These danced and sung memories are accepted and appreciated by the living and the dead.

\section{Bibliography}

Kaeppler, Adrienne L. 1973, 'Music in Hawaii in the nineteenth century', in Robert Günther (ed.), Musikkulturen Asiens, Afrikas und Ozeaniens im 19 Jahrhundert, Gustav Bosse Verlag, Regensburg, Germany, pp. 311-38.

Kaeppler, Adrienne L. 1988, 'Hawaiian tattoo: a conjunction of genealogy and aesthetics', in Arnold Rubin (ed.), Marks of Civilization: Artistic transformations of the human body, Museum of Cultural History, Los Angeles, pp. 157-70.

Kaeppler, Adrienne L. 1993, Hula Pahu Hawaiian Drum Dances. Volume l. Ha 'a and Hula Pahu: sacred movements, Bulletin in Anthropology No. 3, Bishop Museum, Honolulu.

Kaeppler, Adrienne L. 1993, 'Poetics and politics of Tongan laments and eulogies', American Ethnologist, vol. 20, no. 3, pp. 474-501.

Kamakau, Samuel M. 1835, ‘Kahi Mele. He mele Kanikau na Kahekili no ka make ana o kana aikane', Ke Kumu Hawaii, The Mission Press, Honolulu.

Lyons, Rev. C. J. 1895, 'David Malo's lament for Kaahumanu', The Friend, vol. 53, no. 8, pp. 57-58.

Tatar, Elizabeth 1982, Nineteenth Century Hawaiian Chant, Pacific Anthropological Records No. 33, Bishop Museum, Honolulu.

Wong, Ka`upena 2003, 'A Kanikau for palace curator, Jim Bartels', Honolulu Star-Bulletin, 11 May. 